\title{
Obesity, inflammation, and insulin resistance
}

\author{
Luana Mota Martins' ${ }^{1}$, Ana Raquel Soares Oliveira ${ }^{1}$, Kyria Jayanne Clímaco Cruz ${ }^{1}$, \\ Francisco Leonardo Torres-Leal'2, Dilina do Nascimento Marreiro ${ }^{1, *}$
}

\author{
${ }^{1}$ Department of Nutrition, Federal University of Piauí, Campus Ministro Petronio Portella, Teresina, Piauí, Brazil, \\ ${ }^{2}$ Department of Biophysics and Physiology, Federal University of Piauí, Campus Ministro Petrônio Portella, Teresina, \\ Piauí, Brazil
}

\begin{abstract}
White adipose tissue (WAT) is considered an endocrine organ. When present in excess, WAT can influence metabolism via biologically active molecules. Following unregulated production of such molecules, adipose tissue dysfunction results, contributing to complications associated with obesity. Previous studies have implicated pro- and anti-inflammatory substances in the regulation of inflammatory response and in the development of insulin resistance. In obese individuals, pro-inflammatory molecules produced by adipose tissue contribute to the development of insulin resistance and increased risk of cardiovascular disease. On the other hand, the molecules with anti-inflammatory action, that have been associated with the improvement of insulin sensitivity, have your decreased production. Imbalance of these substances contributes significantly to metabolic disorders found in obese individuals. The current review aims to provide updated information regarding the activity of biomolecules produced by WAT.
\end{abstract}

Uniterms: Obesity. Inflammation. Adipose tissue. Adipokines. Insulin resistance.

O tecido adiposo branco (WAT) é considerado um órgão endócrino, que, em excesso, é capaz de controlar o metabolismo, pela ação de moléculas biologicamente ativas. A produção desregulada destas substâncias pela disfunção do tecido adiposo pode contribuir para as complicações presentes na obesidade. As pesquisas atuais têm esclarecido fatores e mecanismos envolvidos na atuação de substâncias pró e anti-inflamatórias na modulação da inflamação e da resistência à insulina. Em indivíduos obesos, as moléculas pró-inflamatórias produzidas pelo tecido adiposo têm sido implicadas como fator contribuinte para o desenvolvimento da resistência à insulina e aumento do risco de doença cardiovascular. Por outro lado, as moléculas com ação anti-inflamatória, que atuam na melhora da sensibilidade à insulina, têm sua produção reduzida. O desequilíbrio entre essas substâncias contribui de forma significativa para as desordens metabólicas presente em indivíduos obesos. Assim, esta revisão visa a trazer informações atualizadas sobre a atuação de moléculas secretadas pelo tecido adiposo.

Unitermos: Obesidade. Inflamação. Tecido adiposo. Adipocinas. Resistência à insulina.

\section{INTRODUCTION}

Obesity is a major worldwide health problem and is strongly associated with a number of diseases, including type 2 diabetes mellitus $\left(\mathrm{T}_{2} \mathrm{DM}\right)$, insulin resistance, atherosclerosis, and ischemic heart disease, which reduce life expectancy. Collectively, these conditions have serious personal, economic, and social consequences. Increasing

\footnotetext{
*Corresponding author: D. N. Marreiro. Departamento de Nutrição, Universidade Federal do Piauí, Campus Universitário Ministro Petrônio Portella, Bairro Ininga, 64049-550 - Teresina - PI, Brasil. Email: dilina.marreiro@gmail.com
}

evidence indicates that obesity is causally linked to a chronic low-grade inflammatory state, shown by increased levels of inflammatory markers (Hotamisligil, Erbay, 2008; Goldfine et al., 2010; Torres-Leal et al., 2010). This contributes directly to the development of obesityrelated diseases, particularly metabolic diseases (Ouchi et al., 2011).

White adipose tissue (WAT) is considered an endocrine organ. When present in excess, it secretes biologically active molecules that influence metabolism by means of adipocyte dysfunction (Fonseca-Alaniz et al., 2006; Fonseca-Alaniz et al., 2007). In this regard, 
several studies have been designed to better understand the regulatory functions of WAT. In recent years, several factors secreted by WAT have been identified that stimulate proinflammatory responses and metabolic dysfunction, thereby promoting the development of obesity and associated metabolic disorders. These findings support the theory that unbalanced production of anti- and pro-inflammatory agents secreted by abdominal visceral adipose tissue contributes significantly to the development of metabolic diseases in the modern world (Ouchi et al., 2011; Capurso, Capurso, 2012).

\section{MOLECULES RELEASED BY ADIPOSE TISSUE}

In recent decades, the physiological action of pro-and anti-inflammatory molecules has been investigated as well as the main factors and mechanisms that influence metabolic disorders in obesity, as shown in Table I and Figure 1.

Adipokine synthesis is regulated by adiposity, and those with pro-inflammatory action are directly related to metabolic dysfunctions found in obesity. Moreover, the levels of anti-inflammatory factors in plasma and in the adipose tissue are decreased in obese individuals compared with lean individuals (McGown, Birerdinc, Younossi, 2014; Ouchi et al., 2011).

\section{SFRP5}

SFRPs (Secreted frizzled-related proteins) are a group of glycoproteins secreted by adipocytes which are capable of binding to both, Wnt and Frizzled receptors (Rattner et al., 1997). Studies in mice have demonstrated that SFRP5 is predominantly expressed in adipocytes; however, in humans the expression of this protein occurs in the cytoplasm of mature adipocytes (Koza et al., 2006; Schulte et al., 2012). Researchers investigating mRNA expression of SFRP5 and other adipokines during adipogenesis observed a significant increase in the expression of SFRP5 during adipogenesis (Lv et al., 2012).

SFRP5 is an important anti-inflammatory adipokine that can prevent obesity and consequently improve insulin sensitivity (Hu, Deng, Qu, 2013; Lv et al., 2012). Studies have shown that adipose tissue from lean individuals secretes larger amounts of SFRP5. Moreover, this protein acts by reducing the production of pro-inflammatory adipokines, such as tumor necrosis factor- $\alpha$ (TNF- $\alpha$ ), interleukin-6 (IL-6), and monocyte chemotactic protein-1 (MCP-1). However, TNF- $\alpha$ can reduce SFRP5 expression by inhibiting adipocyte differentiation and thus, promoting pro-inflammatory signaling via Wnt (Oh, Olefsky, 2010).

Another effect attributed to the adipokine is the ability to bind to Wnt-5a, preventing the activation of pro-inflammatory proteins, thereby contributing to signal transduction in the insulin signaling pathway (Ouchi et al., 2010). Yet, obesity leads to decreased SFRP5 expression and increased Wnt-5a expression in adipocytes, activating the c-jun amino $(\mathrm{N})$-terminal kinase 1 (JNK-1) pathway and triggering a pro-inflammatory response. The activation of JNK-1 impairs the activity of a target protein called insulin receptor substrate-1 (IRS-1) leading to suppressed insulin signaling and development of insulin resistance (Oh, Olefsky, 2010; Ouchi et al., 2010).

In obese rats, Ouchi et al. (2010) observed reduced SFRP5 expression and increased Wnt-5a expression. This confirms that detectable serum levels of Wnt-5a

TABLE I - Pro-and anti-inflammatory adipokines and their functions

\begin{tabular}{ll}
\hline Pro-inflammatory adipokines & Function \\
\hline Leptin & Controls appetite through the central nervous system, increases TNF- $\alpha$ and IL-6 production \\
& in obesity \\
Adipsin & Activates the alternative complement pathway \\
Resistin & Increases insulin resistance \\
RBP-4 & Involved in systemic insulin resistance \\
Lipocalin 2 & Promotes insulin resistance and inflammation \\
TNF- $\alpha$ & Reduces insulin sensitivity, induces lipolysis \\
IL-6 & Reduces insulin sensitivity, induces lipolysis \\
IL-18 & Induces expression of adhesion molecules in endothelial cells and macrophage infiltration in \\
\hline Anti-inflammatory adipokines & Function \\
\hline Adiponectin & Increases insulin sensitivity and anti-apoptotic and pro-angiogenic effects \\
SFRP5 & Improves insulin sensitivity, suppresses pro-inflammatory Wnt signaling \\
\hline
\end{tabular}

Adapted from Ouchi et al., 2010. RBP4, retinol binding protein-4; TNF- $\alpha$, tumor necrosis factor- $\alpha$; IL, interleukin; SFRP5, secreted frizzled-related protein 5 


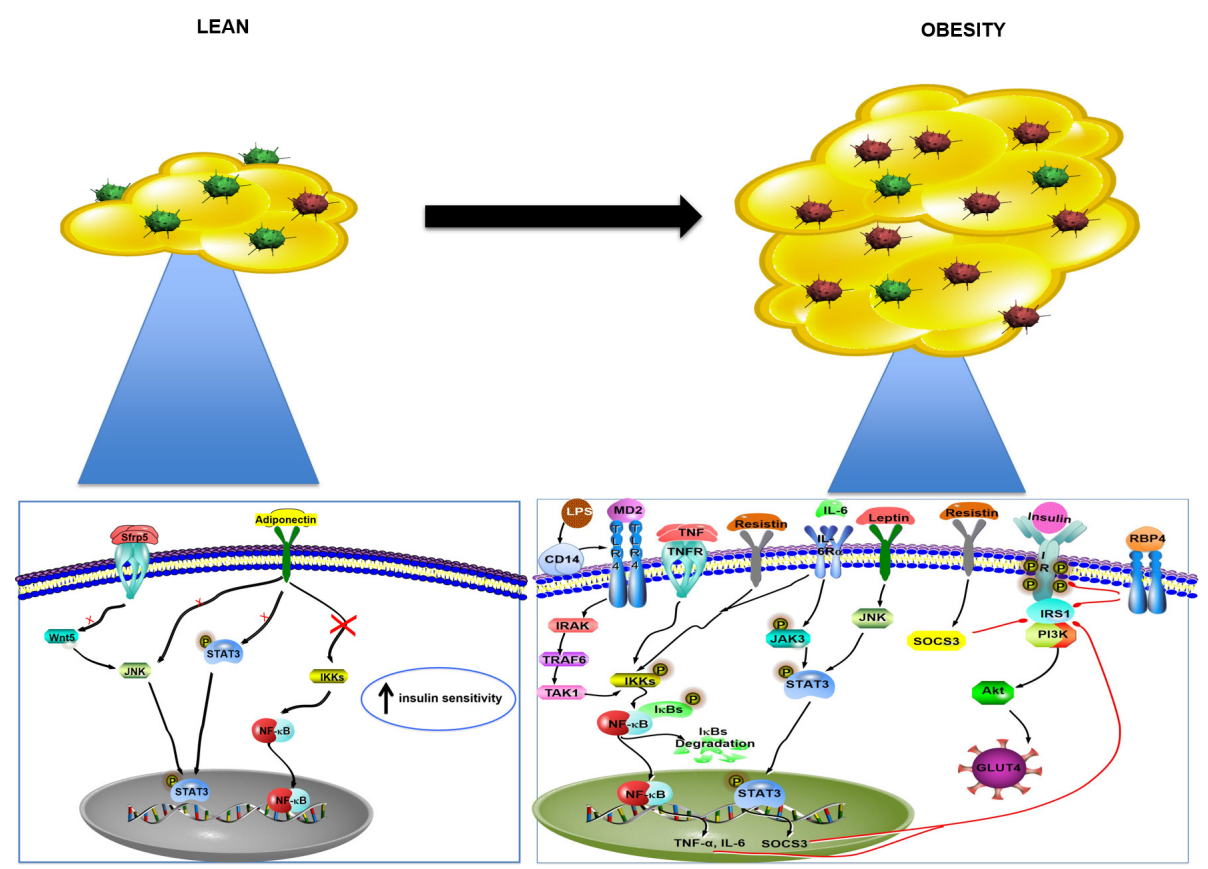

FIGURE 1 - Mechanisms involved in insulin resistance and inflammation present in obesity RBP4, retinol binding protein-4; TNF- $\alpha$, tumor necrosis factor- $\alpha$; IL, interleukin; MCP-1, monocyte chemotactic protein-1; SFRP5, secreted frizzled-related protein 5; LPS, lipopolysaccharide; TLR-4, toll-like receptor 4; JNK, c-jun amino (N)-terminal kinase; STAT3, signal transducer and activator of transcription 3; NF-кB, nuclear factor kappa B; IKK, I kappa B kinase; IRS-1, insulin receptor substrate-1; IR, insulin receptor; TRAF1, tumor necrosis factor receptor-associated factor 1; GLUT4, translocation of glucose transporter 4; SOCS-3, suppressor of cytokine signaling protein-3; TRAF, tumor necrosis factor receptor-associated factor; IRAK, interleukin 1 receptor-associated kinase; PI3K, phosphoinositide 3-kinase; JAK, janus kinase; TAK, transforming growth factor (TGF)-activated kinase $\beta$; CD14, cluster of differentiation-14; MD2, Myeloid differentiation protein-2.

and SFRP5 are present in obese individuals and these bioactive peptides can be affected by level of nutrition. Moreover, SFRP5 exhibited a rapid response to caloric restriction and, after four weeks of dietary intervention, the concentration increased significantly (Schulte et al., 2012).

\section{ADIPONECTIN}

Adiponectin is produced and secreted exclusively by adipocytes and is found in human plasma at concentrations ranging from 3 to $30 \mu \mathrm{g} / \mathrm{mL}$. This adipokine consists of a carboxy-terminal globular domain that binds to two cell surface receptors, adiponectin receptor-1 (AdipoR1) and adiponectin receptor-2 (AdipoR2), expressed differently in various tissues, including WAT. AdipoR1 is predominantly expressed in skeletal muscle, whereas AdipoR2 expression is high in the liver (Folco et al., 2009; Kadowaki, Yamauchi, Kubota, 2008).

Several biochemical processes are thought to be regulated by adiponectin, including activation of AMPactivated protein kinase (AMPK) and the peroxisome proliferator activated receptor- $\alpha$ (PPAR- $\alpha$ ). AMPK activation is dependent on signaling via AdipoR1 while
AdipoR2 appears to be essential for regulating PPAR- $\alpha$ gene expression (Ouchi et al., 2003; Yamauchi et al., 2002; Dyck, 2009; Aprahamian, Sam, 2011; Lin, Li, 2012).

Adiponectin plays an important role in lipid and glucose homeostasis, both directly and as a modulator of insulin sensitivity ( Vu, Riddell, Sweeney, 2007). In addition, it has anti-inflammatory, antiapoptotic, and proangiogenic activity, but mechanisms for these are not well known (Krentz, Von Mühlen, Barrett-Connor, 2009; Landskroner-Eiger et al., 2009).

The mechanism by which adiponectin reduces the activation of inflammatory cells includes inhibition of lipopolysaccharides, decreased T-lymphocyte-activated CXC chemokine receptor 3 (CXCR3) ligand expression on macrophages, decreased phosphorylation of Inhibitor of kappa B (IkB), JNK, signal transducer and activator of transcription 3 (STAT3), and p38, as well as increased expression of IL-10 in leukocytes and genes encoding antiinflammatory proteins such as $\mathrm{A} 20, \mathrm{BCl} 3$, tumor necrosis factor (TNF) receptor-associated factor 1 (TRAF1), suppressor of cytokine signaling protein 3 (SOCS3), and A20-binding inhibitor of NF-kappa-B activation-3 (ABIN3) (Folco et al., 2009). 
Another action of adiponectin is related to macrophage polarization, where M1 type is proinflammatory and $\mathrm{M} 2$ is anti-inflammatory. Adiponectin mRNA reduces M1-type markers, such as TNF- $\alpha$ and MCP1 , and stimulates gene expression of M2 macrophages. Taken together, this confirms that adiponectin has regulatory effects on macrophage polarization, indicating that high expression of this adipokine favors the antiinflammatory phenotype (Ohashi et al. 2010).

Circulating adiponectin levels are reduced in humans as well as in rodent models of obesity and $\mathrm{T}_{2} \mathrm{DM}$ (Krentz, Von Mühlen, Barrett-Connor, 2009). Moreover, accumulation of visceral fat is associated with hypoadiponectinemia (Nakamura et al., 2009), indicating that the synthesis of adiponectin is impaired in obese individuals. Accordingly, adiponectin production by adipocytes is inhibited by pro-inflammatory factors, such as TNF- $\alpha$, IL- 6 , and IL- $1 \beta$, as well as by hypoxia and oxidative stress (Ouchi et al., 2003; Berg, Scherer, 2005; Deng, Scherer, 2011).

In contrast, PPAR $\gamma$ agonists such as thiazolidinediones promote higher expression and secretion of adiponectin via PPAR $\gamma$ activation. Therefore, adiponectin is considered a promising candidate in the development of drugs to treat obesity, insulin resistance, $\mathrm{T}_{2} \mathrm{DM}$, and other metabolic diseases (Wang, Scherer, 2008; Liu, Liu, 2010; Ouchi et al., 2011).

Several clinical observations support the association between adiponectin levels and obesity associated with metabolic dysfunction. First, plasma adiponectin levels correlate negatively with visceral fat accumulation. Second, plasma adiponectin levels are reduced in $\mathrm{T}_{2} \mathrm{DM}$ patients. Third, high adiponectin concentrations are associated with reduced risk of developing $\mathrm{T}_{2} \mathrm{DM}$ (Ouchi et al., 2011). Hypoadiponectinemia has been found in several cardiovascular and metabolic diseases in humans, including $\mathrm{T}_{2} \mathrm{DM}$, lipodystrophy, non-alcoholic fatty liver disease, hypertension, and coronary artery disease (Deng, Scherer, 2011).

Many of the beneficial effects of adiponectin occur via AMPK upregulation in the liver and skeletal muscle (Yamauchi et al., 2002). Adiponectin phosphorylates AMPK, thus inhibiting acetyl CoA carboxylase (ACC) and reducing malonyl CoA levels. Malonyl CoA is an inhibitor of carnitine palmitoyl transferase-1, an enzyme limiting fatty acid oxidation. Consequently, reduction in the levels of malonyl-CoA, which is promoted by AMPK, increases fatty acid oxidation. AMPK also stimulates PPAR- $\alpha$ which increases the expression of enzymes involved in $\beta$-oxidation of fatty acids, resulting in improved insulin sensitivity. Additionally, the peripheral tissues show reduced levels of free fatty acids, which prevents lipotoxicity and impaired insulin receptor signaling by fatty acids (Viollet et al., 2006; Puglisi, Fernandez, 2008).

Adiponectin also reduces hepatic glucose production by directly inhibiting gluconeogenic enzymes (phosphoenolpyruvate carboxykinase and glucose-6phosphate) and by improving glycemic control via insulin sensitivity (Yamauchi et al., 2002; Puglisi, Fernandez, 2008). Increased AMPK, as a result of adiponectin action, promotes higher fatty acid oxidation in skeletal muscle and decreases the distribution of nonesterified fatty acids to the liver, leading to reduced triacylglycerol synthesis and very low density lipoprotein cholesterol (VLDL) secretion (Puglisi, Fernandez, 2008).

\section{LEPTIN}

Leptin, a 16-kDa protein containing 167 amino acids, is highly hydrophilic and is synthesized by WAT. It acts on food control and energy expenditure via Lepr-b receptor on neurons. These neurons, such as Lepr-b, are required for leptin action (Myers et al., 2009). In general, hypothalamus, midbrain, and brainstem, where these neurons are located, are known to play important roles in the energy metabolism and balance (Sadagurski et al., 2012).

The regulation of energy metabolism by leptin is two-fold. The first action is to stimulate the expression of neuropeptides that promote inhibition of food intake and increase total energy expenditure within parvocellular neurons in the hypothalamic arcuate nucleus (ARC). This involves a population of neurons from the paraventricular nucleus promoting increased sympathetic tone. The second action is to inhibit the expression of neuropeptide $Y$ (NPY) and agouti peptide (AGRP), involved in increased food intake and reduced energy expenditure, acting on a similar population of neurons within the ARC itself (Fonseca-Alaniz et al., 2007).

Under normal conditions, leptin activity increases the expression of anorexigenic peptides and decreases the expression of orexigenic peptides in specific neuron populations. This decreases appetite and increases energy expenditure, contributing to the maintenance of metabolic balance. In contrast, the effects of leptin on energy homeostasis is decreased in pathological conditions such as obesity, due to physiological activity from the excessive adipose tissue (St-Pierre, Tremblay, 2012).

It is well established that obese individuals are less sensitive to leptin action, and that they are resistant to this hormone. Several mechanisms have been proposed to explain this resistance, including impaired leptin transport across the blood-brain barrier, endoplasmic reticulum stress 
and inflammation, as well as attenuated leptin signaling by SOCS3 and protein tyrosine phosphatase (PTP) (Ozcan et al., 2009; Zhang, Scarpace, 2009; Myers et al., 2012).

Recent studies indicate that the changes caused by obesity are mediated, at least in part through activation of Toll-like receptors (TLRs) in various tissues and that this signaling contributes to the development of obesity associated with insulin resistance (Könner, Brüning, 2011; Fortis et al., 2012). Obese individuals and those with $\mathrm{T}_{2} \mathrm{DM}$ have elevated gene and protein TLR 4 expression in muscle tissue, which correlates with the severity of insulin resistance in these conditions. Abnormal TLR4 expression and signaling caused by elevated levels of free fatty acid (FFA) may contribute to the pathogenesis of insulin resistance in humans. Diets high in saturated fats are considered causes of leptin and insulin resistance induced by diet. Saturated fat acts as a TLR4 ligand, thus activating cascade of JNK and IKK signaling pathways, and inhibiting insulin action in the skeletal muscle, liver and WAT (Wellen, Hotamisligil, 2005; Reyna et al., 2008).

Leptin is involved in insulin sensitivity through the immune response and other mechanisms, such as signaling in neuron receptors. In this regard, studies have revealed that IRS-2 signaling in Lepr-b neurons is the key mediator for insulin/insulin-like growth factor (IGF) signaling in the brain and in controlling energy balance. Action of insulin, IGF1 and IGF2 via the receptor tyrosine kinase sends signals to proteins such as the insulin receptor substrate, IRS-1, IRS-2, and IRS-4 (White, 2010; Sadagurski et al., 2012).

Recently, researchers have highlighted antidiabetic action of leptin in experimental models (Fujikawa et $a l ., 2013)$. Leptin is secreted primarily from WAT and binds to its receptor (LEPR) in GABAergic neurons, that secrete gamma-aminobutyric acid (GABA) as well as pro-opiomelanocortin neurons (POMC), thus exerting antidiabetic action in insulin deficient conditions. Leptin inhibits AGRP/NPY/GABA neurons, while it activates POMC neurons in the ARC. The anti-diabetic activity of leptin probably occurs in second-order neurons located in the paraventricular nucleus $(\mathrm{PVH})$, the lateral $(\mathrm{LH})$, and ventromedial (VMH) hypothalamus, or brainstem. The LEPR in GABAergic neurons in other hypothalamic regions, such as the dorsomedial hypothalamus (DMH) or LH may also mediate leptin activity on glucose homeostasis. Leptin suppresses hyperglucagonemia and increases glucose utilization in peripheral tissues such as brown adipose tissue and skeletal muscle, through its activity on GABAergic and POMC neurons (Fujikawa et al., 2013; Kahn, Minokoshi, 2013).

The adipokine leptin is structurally similar to the family of cytokines with helicoidal form, such as IL-2 and growth hormone, promoting a pro-inflammatory activity. Here, leptin increases the production of TNF- $\alpha$ and IL6 , thus stimulating the production of reactive oxygen species (ROSs). Leptin also promotes cell differentiation and migration responses by monocytes, in addition to stimulating the production of CC-chemokine ligands (CCL-3, CCL-4, CCL-5) by activating JAK2-STAT3 in macrophages (Santos-Alvarez, Goberna, SánchezMargalet, 1999; Kiguchi et al., 2009).

In rodents and humans, leptin deficiency results in obesity due to hyperphagia and low energy expenditure by the central nervous system (CNS), namely low energy levels in the presence of sufficient energy reserves. In diet-induced obesity, leptin levels are high, reflecting increased fat depots (Myers et al., 2010; Torres-Leal et al., 2011). Studies in healthy humans have demonstrated that moderate weight gain increases the expression of adipokines and alters the expression of caveolin 1 in WAT. This in turn, affects leptin signaling and inhibits the accumulation of lipids in adipose cells (Singh et al., 2012).

\section{RETINOL BINDING PROTEIN 4}

Retinol binding protein-4 (RBP-4), a member of the lipocalin family, is a vitamin A transporting protein in plasma. It is mainly synthesized by hepatocytes and secreted into circulation in the form of retinol-RBP complex, which provides retinol to the tissues. WAT is the second largest site of RBP-4 expression. Recent studies have shown that this protein is involved in the induction of insulin resistance, and thus, it is considered important for the development of $\mathrm{T}_{2} \mathrm{DM}$ (Blaner et al., 1986; Zhang, Yang, Shi, 2005; Bajzová et al., 2008).

RBP-4 levels have a positive correlation with adipocyte size and inflammatory markers such as waist circumference and body mass index. RBP-4 levels are preferably expressed in visceral WAT rather than subcutaneous WAT (Klöting et al., 2007; Lee, Lee, Im, 2007; Hermsdorff et al., 2011). The expansion of adipocyte tissue reduces adiponectin expression and increases circulating levels of RBP-4. These changes are associated with low oxidation rate of fatty acids, increased gluconeogenesis in the liver, decrease in IRS-1 phosphorylation, and translocation of glucose transporter (GLUT4), which results in insulin resistance (Gavi et al., 2007; Esteve, Ricart, Fernández-Real, 2009; Yang et al., 2005).

In childhood obesity, high RBP-4 levels are associated with excessive body fat, insulin resistance, $\mathrm{T}_{2} \mathrm{DM}$, and circulating inflammatory factors, such as C-reactive protein (CRP) and IL-6 (Balagopal et al., 
2007). Furthermore, it was found that IL-8 increases RBP4 gene expression in the adipocyte and this can contribute to increased incidence of DM (Bobbert et al., 2009).

On the other hand, some studies diverge on the role of RBP-4 in obese individuals without insulin resistance. Accordingly, Choi et al. (2009) compared RBP-4 levels associated with weight loss in non-diabetic obese individuals and observed no significant difference between the study groups. In contrast, RBP-4 expression, insulin resistance, PCR, IL-18, and TNF- $\alpha$ levels decreased significantly, while adiponectin increased significantly with weight loss in obese women (Broch et al., 2010).

\section{LIPOCALIN 2}

Lipocalin 2 (Lcn2), also known as $24 \mathrm{p} 3$ or neutrophil gelatinase-associated lipocalin, is a $25-\mathrm{kDa}$ glycoprotein originally identified in mouse kidney cells and human neutrophil granules (Wang et al., 2007; Choi et al., 2008). This cytokine is a member of the lipocalin family and has a tertiary barrel-shaped structure with a hydrophobic pocket that can bind to lipophilic molecules such as retinol, fatty acids, and steroids (Esteve, Ricart, Fernández-Real, 2009; Ouchi et al., 2011; Kamata et al., 2012).

This protein has been implicated in apoptosis, cancer, inflammation, iron homeostasis, and innate immunity. In addition to neutrophils, Len2 is expressed in many tissues including the liver, lung, kidney, adipocytes, and macrophages. Several inflammatory stimuli, such as lipopolysaccharide and IL-1, can promote Lcn 2 expression and secretion. Pro-inflammatory transcription factor NF$\kappa \mathrm{B}$ activates Len 2 expression by binding to the promoter region of gene Lcn2, suggesting its involvement in the inflammatory response (Wang et al., 2007; Law et al., 2010; El-Mesallamy et al., 2012; Kamata et al., 2012).

Lcn 2 has been identified as an acute-phase protein secreted by WAT and is positively correlated with potential effects on obesity, inflammation, apoptosis, and innate immunity (Damirchi, Rahmani-Nia, Mehrabani, 2011). Lcn 2 expression is increased by agents promoting insulin resistance, and reduced by thiazolidinediones, indicating a role in insulin resistance in obesity (Yan et al., 2007; Fried, Greenberg, 2012). Furthermore, high Lcn2 levels are associated with a decline in pancreatic $\beta$-cell function in diabetic patients (El-Mesallamy et al., 2012).

In a study on diabetic and obese $(d b-d b)$ mice conducted by Wang et al. (2007), circulating Lcn2 levels and its expression were increased in WAT and liver compared with those in control mice. In addition, serum Lcn2 levels positively correlated with body mass index, hypertriglyceridemia, hyperglycemia, and insulin resistance, but negatively correlated with high-density lipoprotein (HDL-c) in humans. In the same study, treatment with rosiglitazone significantly decreased Lcn2 levels and gene expression. The authors suggest that Len2 is an inflammatory marker closely linked to obesity and its metabolic complications.

Lcn 2 expression is increased in atherosclerotic plaques and myocardial infarction, while it regulates the inflammatory response during ischemia and reperfusion during heart transplantation. In this regard, Choi et al. (2008) identified higher circulating Lcn2 levels in individuals with coronary artery disease than those in the control group. Additionally they found a positive correlation of Len 2 with body weight, fasting insulin levels, and insulin resistance.

Len2 has recently been associated with antiinflammatory effects. High concentrations of this protein in obesity and insulin resistance appear to protect against inflammation. Furthermore, Lcn 2 regulates PPAR- $\gamma$ in adipocytes as well as its target genes, adiponectin, leptin, fatty acid synthase, and lipoprotein lipase. The anti-inflammatory function of Len2 is associated with modulation on PPAR $\gamma$ activity, which, by direct or indirect mechanisms, inhibits NF- $\kappa \mathrm{B}$ activity. Concomitantly, Lcn 2 antagonizes the effects of TNF- $\alpha$ in adipocytes and macrophages, protecting these cells from TNF- $\alpha$ production induced by IL- 6 and MCP-1. Thus, Len2 mitigates the effect of TNF- $\alpha$ on glucose uptake and reverses the inhibitory effect of TNF- $\alpha$ on leptin and adiponectin secretion by adipocytes (Zhang et al., 2008; Esteve, Ricart, Fernández-Real, 2009).

\section{INTERLEUKIN-6}

Interleukin-6 is a pro-inflammatory cytokine that is also involved in insulin resistance found in obesity. IL-6 levels correlates positively with adiposity in humans, wherein, obese individuals have high IL-6 levels and weight loss promotes reduced production of this cytokine (Ziccardi et al., 2002; Iacobellis, Leonetti, 2005; Ouchi et al., 2011).

IL-6 acts on carbohydrate and lipid metabolism, stimulating lipolysis with consequent inhibition of enzyme lipoprotein lipase and increased release of free fatty acids and glycerol. IL-6 is a central mediator of the acute-phase response, and is produced and secreted by endothelial cells, smooth muscle cells, monocytes, macrophages, and adipocytes, especially visceral adipose tissue (Rexrode et al., 2003; Fonseca-Alaniz et al., 2006; Francisco, Hernández, Simó, 2006).

IL-6 infusion at doses close to physiological levels in healthy humans promotes lipolysis, regardless modulation 
of catecholamines, glucagon, and insulin. This effect occurs through inhibition of lipoprotein lipase (LPL) and increased release of FFA and glycerol. IL-6 is secreted by macrophages and adipocytes, and its expression can be stimulated by high concentrations of catecholamines via adrenergic $\beta 2$ - and $\beta 3$-receptors from WAT (FonsecaAlaniz et al., 2007).

IL-6 is positively associated with waist circumference, suggesting that increased body fat, especially central obesity, promotes the development of metabolic syndrome and insulin resistance (Rexrode et al., 2003; Volp et al., 2008; Junqueira, Romêo Filho, Junqueira, 2009). Some studies show a clear relationship between high IL-6 levels and the presence of insulin resistance or $\mathrm{T}_{2} \mathrm{DM}$. This cytokine reduces insulin-dependent glycogen synthesis and glucose uptake in adipocytes through increased expression of SOCS-3, a protein that binds to and inhibits insulin receptor. Additionally, it negatively regulates IRS-1 phosphorylation and transcription (Galic, Oakhill, Steinberg, 2010; Torres-Leal et al., 2010).

Studies have shown that higher the body mass index and waist circumference, higher the inflammatory markers levels. The study conducted by Rexrode et al. (2003) showed that women with body mass index greater than $28.3 \mathrm{~kg} / \mathrm{m}^{2}$ have four times the IL-6 levels found in those with body mass index within the normal range. Similarly, individuals with visceral obesity have significantly higher serum IL-6 levels than those in eutrophic individuals (Nishida et al., 2007). By contrast, reduced serum IL-6 levels were found in individuals who had weight loss (Esposito et al., 2003).

In a study on overweight male individuals, Spalding et al. noted that circulating IL-6 levels were associated with visceral obesity whereas TNF- $\alpha$ was associated with overall obesity (Spalding et al., 2008). According to the author, these results support the hypothesis that IL-6 is involved in the hyperinsulinemic state associated with excessive visceral fat, whereas TNF- $\alpha$ appears to contribute to insulin resistance in overall obesity.

\section{RESISTIN}

Resistin (RETN) belongs to the family of cysteinerich peptides termed resistin-like molecules (RELM) (Steppan et al., 2001). This cytokine is expressed and secreted by rodent adipocytes and the name is derived from its ability to induce insulin resistance. RETN is associated with activation of inflammatory processes (Steppan et al., 2001), where circulating levels increase even though mRNA levels are reduced, in genetically modified models and a high-fat diet (Steppan et al., 2001; Rajala et al., 2004; Way et al., 2001).
In experimental mouse models, RETN showed ability to induce insulin resistance (Steppan et al., 2001) and low fasting glucose levels were seen in RETNknockout animals due to low hepatic glucose production (Banerjee et al., 2004). Ob-ob resistin deficient mice were more obese although showing increased insulin sensitivity and improved glucose tolerance (Qi et al., 2006).

From this perspective, the ability of RETN to affect glucose metabolism is associated with activation of SOCS3 , an inhibitor of insulin signaling in adipocytes (Steppan et al., 2005). Although studies in animal models have consistently shown that RETN promotes insulin resistance, there is also evidence indicating that this effect in humans is less evident (Lee et al., 2003; Heilbronn et al., 2004).

The trimer isoform of RETN is the most bioactive and is primarily responsible for hepatic insulin resistance; however, it is less abundant (Patel et al., 2004). Although RETN was originally identified in WAT, new studies show a more systemic pattern of expression, which had led to a controversy over the regulation of this adipokine. In mice, protein synthesis of RETN is restricted to adipocytes (Steppan et al., 2001), whereas, in humans, it is mainly produced by macrophages and monocytes, and is not detectable in adipocytes (Savage et al., 2001).

Studies in human mononuclear cells show that RETN gene transcription is stimulated by proinflammatory cytokines (IL-1, IL-6, and TNF- $\alpha$ ) (Kaser et al., 2003) and is inhibited by PPAR $\gamma$ agonists in WAT (e.g., rosiglitazone), suggesting that the anti-inflammatory effect of these agonists is mediated, in part by attenuation of RETN transcription (Lehrke et al., 2004).

Moreover, studies performed in mice lacking adipocyte-derived mouse RETN, but expressing human transgene RETN in macrophages showed that pro-inflammatory properties of RETN contribute to insulin resistance in vivo (Qatanani et al., 2009). The pro-inflammatory role of RETN in mononuclear cells is characterized by promoting TNF- $\alpha$ and IL- 6 expression in these cells (Bokarewa et al., 2005). On the other hand, RETN acts by directly antagonizing the anti-inflammatory effects of adiponectin in vascular endothelial cells, inducing expression of pro-inflammatory molecules, such as vascular cell adhesion molecule-1 (VCAM1), intercellular adhesion molecule-1 (ICAM-1), and pentraxin-3, increasing leukocyte adhesion (Verma et al., 2003; Kawanami et al., 2004).

\section{TUMOR NECROSIS FACTOR ALPHA}

TNF- $\alpha$, an inflammatory and immunomodulatory cytokine that acts directly on the adipocyte, has been 
implicated in metabolic diseases, including obesity and insulin resistance (Puglisi, Fernandez, 2008). This cytokine was initially identified as a polypeptide produced by macrophages in chronic diseases as well as during infectious processes contributing to cachexia (Rose, Komninou, Stephenson, 2004). In WAT, TNF- $\alpha$ is synthesized and secreted by vascular stromal cells and matrix fractions including macrophages, although its mRNA is expressed in adipocytes (Fain, Bahouth, Madan, 2004).

Obesity is associated with increased FFA resulting from triglyceride lipolysis in the adipocyte. The relationship between obesity and inflammation has been reported as high TNF- $\alpha$ expression in WAT (De Carvalho, Colaço, Fortes, 2006). Studies have shown a positive correlation between plasma TNF- $\alpha$ concentrations, body mass index, and triacylglycerols. This cytokine is produced 7.5 times higher by the WAT in obese individuals than that in non-obese individuals. Furthermore, there is evidence indicating that TNF- $\alpha$ promotes increased production of VLDL particles, which may explain its direct relationship with plasma triacylglycerols (Deng, Scherer, 2011).

Studies have shown that TNF- $\alpha$ is also associated with insulin resistance in obesity. Accordingly, high TNF- $\alpha$ expression in subcutaneous WAT promotes increased insulin levels in obesity, as typically seen in insulin resistance. TNF- $\alpha$ induces insulin resistance by promoting lipolysis, consequently promoting increased circulating levels of FFA and reduced protein expression of GLUT4, insulin receptor, and IRS-1 (Fonseca-Alaniz et al., 2007).

In this context, macrophage infiltration in WAT results in increased TNF- $\alpha$ secretion, and this, in turn, activates both lipolysis and $\mathrm{NF}-\kappa \mathrm{B}$, via receptors (TNF-R) located in the adipocytes. Furthermore, saturated fatty acids (resulting from lipolysis in the adipocytes) are involved in TLR activation by macrophages and adipocytes. These receptors also favor the activation of $\mathrm{NF}-\kappa \mathrm{B}$, which increases the secretion of inflammatory cytokines in both cells. Thus, IRS-1 phosphorylation is reduced, leading to insulin resistance (Fortis et al., 2012).

TNF- $\alpha$ plays a key role in the transcription cascade of other cytokines and growth factors in the inflammatory process. Elevated TNF- $\alpha$ contributes to the synthesis of interleukins such as IL-1, IL-6, and IL-8, which in turn induce monocyte adhesion, thus promoting the atherosclerotic process (Li, Verma, 2002; Puglisi, Fernandez, 2008).

TNF- $\alpha$ activates IkB via kinase complex IKK, which in turn leads to polyubiquitination and subsequent degradation by IkB protease. Consequently, NF- $\kappa \mathrm{B}$ is phosphorylated and dissociated from $\mathrm{IkB}$, and translocated to the nucleus where it binds to promoter regions of genes responsive to NF- $\mathrm{\kappa B}$, thus initiating the transcription of pro-inflammatory genes, such as IL-1, IL-6, and TNF- $\alpha$ (Li, Verma, 2002; Hayden, Ghosh, 2004). Current studies suggest that TNF- $\alpha$ induces IL- 6 synthesis by NF- $\kappa B$ phosphorylation and that oxidative stress also contributes to the synthesis of this cytokine (Tanabe et al., 2010).

WAT from normal individuals is involved in adiponectin production by increasing insulin sensitivity. However, WAT from obese individuals has impaired adiponectin secretion, thus compromising insulin action. From this perspective, increased insulin resistance and TNF- $\alpha$ expression contribute to decreased adiponectin gene expression (Hajri et al., 2011). Increased expression of TNF- $\alpha$ and IL- 6 confirms that obese diabetic individuals have a more severe inflammatory state than that in nonobese diabetic ones (Goyal et al., 2010).

Human adipocytes exposed to TNF- $\alpha$ exhibit reduced PPAR $\beta / \delta$ activity and this effect depends on NF$\kappa \mathrm{B}$ activation. Moreover, this response is recovered by $\mathrm{PPAR} \beta / \delta$ agonists, suggesting that inhibition of NF- $\kappa \mathrm{B}$ by these drugs can avoid metabolic dysfunction in obese individuals (Serrano-Marco et al., 2012). Another effect attributed to TNF- $\alpha$ is reduced production of zinc $\alpha-2$ glycoprotein (ZAG), a protein modulating body weight, which hydrolyzes TAG via hormone sensitive lipase (HSL), contributing to increased lipid droplets in WAT and ectopic accumulation in the liver and other peripheral tissues (Rolli et al., 2007; Mracek et al., 2010).

\section{LITAF (LIPOPOLYSACCHARIDE-INDUCED TNF- $\alpha$ FACTOR)}

LITAF is a transcription factor that binds to a regulatory element (CTCCC) in the TNF- $\alpha$ promoter region, induces transcription of TNF- $\alpha$, and is likely to be related to the defense against infections. LITAF induced by lipopolysaccharide and signal transducer and activator of transcription 6 (STAT6B), form a complex in the cytoplasm that translocates into the nucleus. Consequently, it increases the expression of TNF- $\alpha$, IL- $1 \alpha$, IL-10, interferon-gamma (IFN- $\gamma$ ), and MCP-2 (Tang, Fenton, Amar, 2003; Tang et al., 2005; Srinivasan, Leeman, Amar, 2010).

LITAF expression can be increased by lipopolysaccharide stimulation in human monocytes and rat macrophages via activation of receptors TLR2 and TLR4 (Tang et al., 2006). Studies have demonstrated the relationship between this protein and obesity, insulin resistance, and inflammatory cytokines. LITAF is activated in obese patients and is involved in inflammation 
and insulin resistance found in obesity, through regulation of TNF- $\alpha$, IL- 6 and MCP- 2 expression. Moreover, TLR-4 is a membrane receptor found in macrophages stimulated by both LITAF and FFA, thus initiating the inflammatory process via NF- $\kappa \mathrm{B}(\mathrm{Ji}, \mathrm{Dai}, \mathrm{Xu}, 2011)$.

\section{LIPOKINE}

It is well established that the imbalance between energy intake and expenditure has a direct influence on adiposity gain (Flowers, Ntambi, 2009). This increase in the adipose content can occur in two ways: hypertrophy and hyperplasia (Torres-Leal et al., 2010). The ability of adipose tissue to expand is considered critical when it comes to changes in the energy availability, but this ability is limited and is likely to vary among individuals (Gray, Vidal-Puig, 2007; Virtue, Vidal-Puig, 2010). Investigators suggest that it is not the absolute amount of adipose tissue, but the adipocyte ability to expand that affects metabolic homeostasis (Gray, Vidal-Puig, 2007; Virtue, Vidal-Puig, 2010). Furthermore, it is known that adipocyte size is critical to changes in both, its role as an endocrine organ, and its metabolism (lipogenesis and lipolysis).

Recently, considerable attention has been given to the effect of the enzyme stearoyl-coenzyme A desaturase (SCD), which primarily affects fat storage (Flowers, Ntambi, 2008; Popeijus, Saris, Mensink, 2008; Gong et al., 2011). SCD is involved in de novo synthesis of monounsaturated fatty acids from saturated fatty acids (Smith, Lieberman, Marks, 2005). The main products of SCDs are palmitoleic (16:1 $\omega-7)$ and oleic (18:1) acid, essential for triacylglycerol synthesis (Smith, Lieberman, Marks, 2005), from their preferred substrates, palmitic (16:0) and stearic acid (18:0), respectively. Two SCD isoforms have been observed in humans, SCD1 (mainly seen in adipose tissue and liver) and SCD5 (observed in the brain and pancreas) (Zhang et al., 1999; Wang et al., 2005; Zhang, Yang, Shi, 2005).

Studies to date indicate that - amongst the molecules synthesized and secreted by WAT - palmitoleic acid, which is considered as the most common lipid signaling agent with hormonal functions, controls metabolic activities in the liver and skeletal muscle, such as stimulating insulin action in muscle and suppressing liver steatosis (Cao et al., 2008).

Cao et al. point out that palmitoleic acid production is higher in fatty acid binding protein-(FABP) or chaperone-knockout mice; where these proteins help to transport and store the fat absorbed from food into adipocytes. This study revealed that impaired lipid storage induced by diet causes the adipocytes to synthesize their own fat, which in turn increases palmitoleic acid production, thereby promoting a healthy metabolism. Moreover, these FABP/knockout mice were resistant to chronic high fat diet-associated problems, such as heart disease, liver steatosis, and diabetes (Cao et al., 2008). However, little is known about the effects of lipokine on WAT metabolism, as well as in adipogenesis.

Recently, the involvement of palmitoleic acid in WAT metabolism (lipogenesis and lipolysis) was investigated. The results indicated that palmitoleic acid is an important positive modulator of lipolysis in adipocytes and acts by increasing protein expression of lipases such as ATGL and HSL, through a PPAR- $\alpha$ dependent mechanism (Bolsoni-Lopes et al., 2013). However, further studies are required to test whether activation of lipolysis by lipases and palmitoleic acid has protective effects against excessive fat deposition found in obesity.

\section{CONCLUSION}

Evidence found in this review suggests that chronic inflammatory state associated with obesity, particularly visceral fat accumulation, contributes to several metabolic and hormonal disturbances. In this regard, it is worth noting that excessive adipose tissue increases the production of adipokines with pro-inflammatory action at the expense of adipokines with anti-inflammatory action. Therefore, this article provides information regarding new molecules in order to help understand the influence of adipokines in adipose tissue-mediated inflammation and insulin resistance.

\section{CONFLICT OF INTEREST}

The authors have no conflicts of interest to declare.

\section{REFERENCES}

APRAHAMIAN, T.R.; SAM, F. Adiponectin in cardiovascular inflammation and obesity. Int. J. Inflamm., v.2011, n.376909, p.1-8, 2011.

BAJZOVÁ, M.; KOVÁCIKOVÁ, M.; VÍTKOVÁ, M. , KLIMČÁKOVÁ, E.; POLÁK, J.; KOVÁČOVÁ, Z., VIGUERIE, N.; VEDRAL, T.; MIKULÁŠEK, L.; ŠRÁMKOVÁ, P.; SRP, A.; HEJNOVÁ, J.; LANGIN, D.; ŠTICH, V. Retinol-binding protein 4 expression in visceral and subcutaneous fat in human obesity. Physiol. Res., v.57, n.6, p.927-934, 2008. 
BALAGOPAL, P.; GRAHAM, T.E.; KAHN, B.B.;ALTOMARE, A.; FUNANAGE, V.; GEORGE, D. Reduction of elevated serum retinol binding protein in obese children by lifestyle intervention: association with subclinical inflammation. $J$. Clin. Endocrinol. Metab., v.92, n.5, p.1971-1974, 2007.

BANERJEE, R.R.; RANGWALA, S.M.; SHAPIRO, J.S.; RICH, A.S.; RHOADES, B.; QI, Y.; WANG, J.; RAJALA, M.W.; POCAI, A.; SCHERER, P.E.; STEPPAN, C.M.; AHIMA, R.S.; OBICI, S.; ROSSETTI, L.; LAZAR, M.A. Regulation of fasted blood glucose by resistin. Science, v.303, n.5661, p.1195-1198, 2004.

BERG, A.H.; SCHERER, P.E. Adipose tissue, inflammation, and cardiovascular disease. Circ. Res., v.96, n.9, p.939949, 2005.

BLANER, W.S.; DAS, K.; MERTZ, J.R.; DAS, S.R.; GOODMAN, D.S. Effects of dietary retinoic acid on cellular retinol- and retinoic acid-binding protein levels in various rat tissues. J. Lipid. Res., v.27, n.10, p.1084-1088, 1986.

BOBBERT, P.; WEITHÄUSER, A.; ANDRES, J.; BOBBERT, T.; KÜHL, U.; SCHULTHEISS, H.P.; RAUCH, U.; SKURK, C. Increased plasma retinol binding protein 4 levels in patients with inflammatory cardiomyopathy. Eur. J. Heart. Fail., v.11, n.12, p.1163-1168, 2009.

BOKAREWA, M.; NAGAEV, I.; DAHLBERG, L.; SMITH, U.; TARKOWSKI, A. Resistin, an adipokine with potent proinflammatory properties. J. Immunol., v.174, n.9, p.5789-5795, 2005.

BOLSONI-LOPES, A.; FESTUCCIA, W.T.; FARIAS, T.M.; CHIMIN, P.; TORRES-LEAL, F.L.; DEROGIS, P.B.M.; ANDRADE, P.B.; MIYAMOTO, S.; LIMA, F.B.; CURI, R.; ALONSO-VALE, M.I.C. Palmitoleic acid (n-7) increases white adipocyte lipolysis and lipases content in a PPAR $\alpha$ dependent manner. Am. J. Physiol. Endocrinol. Metab., v.305, n.9, p.1093-102, 2013.

BROCH, M.; GÓMEZ, J.M.; AUGUET, M.T.; VILARRASA, N.; PASTOR, R.; ELIO, I.; OLONA, M.; GARCÍAESPAÑA, A.; RICHART, C. Association of retinol-binding protein-4 (RBP4) with lipid parameters in obese women. Obes. Surg., v.20, n.9, p.1258-1264, 2010.
CAO, H.; GERHOLD, K.; MAYERS, J.R.; WIEST, M.M.; WATKINS, S.M.; HOTAMISLIGIL, G.S. Identification of a lipokine, a lipid hormone linking adipose tissue to systemic metabolism. Cell, v.134, n.6, p.933-944, 2008.

CAPURSO, C.; CAPURSO, A. From excess adiposity to insulin resistance: the role of free fatty acids. Vasc. Pharmacol., v.57, n.2-4, p.91-97, 2012.

CHOI, K.M.; KIM, T.N.; YOO, H.J.; LEE, K.W.; HWANG, T.G.; BAIK, S.H.; CHOI, D.S.; KIM, S.M. Effect of exercise training on A-FABP, lipocalin-2 and RBP4 levels in obese women. Clin. Endocrinol., v.70, n.4, p.569-574, 2009.

CHOI, K.M.; LEE, J.S.; KIM, T.N.; BAIK, S.H.; SEO, H.S.; CHOI, D.S.; OH, D.J, PARK, C.G. Implication of lipocalin-2 and visfatin levels in patients with coronary heart disease. Eur. J. Endocrinol., v.158, n.2, p.203-207, 2008 .

DAMIRCHI, A.; RAHMANI-NIA, F.; MEHRABANI, J. Lipocalin-2: response to a progressive treadmill protocol in obese and normal-weight men. Asian J. Sports Med., v.2, n.1, p.44-50, 2011

DE CARVALHO, M.H.; COLAÇO, A.L.; FORTES, Z.B. Cytokines, endothelial dysfunction, and insulin resistance. Arq. Bras. Endocrinol. Metab., v.50, n.2, p.304-312, 2006.

DENG, Y.; SCHERER, P.E. Adipokines as novel biomarkers and regulators of the metabolic syndrome. Ann. N.Y. Acad. Sci., v.1226, n.1, p.50, 2011.

DYCK, D.J. Adipokines as regulators of muscle metabolism and insulin sensitivity. Appl. Physiol. Nutr. Metab., v.34, n.3, p.396-402, 2009.

EL-MESALLAMY, H.O.; HAMDY, N.M.; ZAGHLOUL, A.S.; SALLAM, A.M. Clinical value of circulating lipocalins and insulin-like growth factor axis in pancreatic cancer diagnosis. Pancreas, v.42, n.1, p.149-154, 2012.

ESPOSITO, K.; PONTILLO, A.; DI PALO, C.; GIUGLIANO G.; MASELLA, M.; GIUGLIANO, D. Effect of weight loss and lifestyle changes on vascular inflammatory markers in obese women: a randomized trial. JAMA, v.289, n.14, p.1799-804, 2003. 
ESTEVE, E.; RICART, W.; FERNÁNDEZ-REAL, J.M. Adipocytokines and insulin resistance: the possible role of lipocalin-2, retinol binding protein-4, and adiponectin. Diabetes Care, v.32, suppl.2, p.S362-S367, 2009.

FAIN, J.N.; BAHOUTH, S.W.; MADAN, A.K. TNFalpha release by the nonfat cells of human adipose tissue. Int. J. Obes. Relat. Metab. Disord., v.28, n.4, p.616-622, 2004.

FLOWERS, M.T.; NTAMBI, J.M. Role of stearoyl-coenzyme A desaturase in regulating lipid metabolism. Curr. Opin. Lipidol., v.19, n.3, p.248-256, 2008.

FLOWERS, M.T.; NTAMBI, J.M. Stearoyl-CoA desaturase and its relation to high-carbohydrate diets and obesity. Biochim. Biophys. Acta, v.1791, n.2, p.85-91, 2009.

FOLCO, E.J.; ROCHA, V.Z.; LÓPEZ-ILASACA, M.; LIBBY, P. Adiponectin Inhibits Pro-inflammatory Signaling in Human Macrophages Independent of Interleukin-10. J. Biol. Chem., v.284, n.38,p.25569-25575, 2009.

FONSECA-ALANIZ, M.H.; TAKADA, J.; ALONSO-VALE, M.I.; LIMA, F.B. The adipose tissue as a regulatory center of the metabolism. Arq. Bras. Endocrinol. Metab., v.50, n.2, p.216-129, 2006.

FONSECA-ALANIZ, M.H.; TAKADA, J.; ALONSOVALE, M.I.; LIMA, F.B. Adipose tissue as an endocrine organ: from theory to practice. J. Pediatr., v.83, suppl.5, p.S192-S203, 2007.

FORTIS, A.; GARCÍA-MACEDO, R.; MALDONADOBERNAL, C.; ALARCÓN-AGUILAR, F.; CRUZ, M. The role of innate immunity in obesity. Salud. Publica Mex., v.54, n.2, p.171-177, 2012.

FRANCISCO, G.; HERNÁNDEZ, C.; SIMÓ, R. Serum markers of vascular inflammation in dyslipemia. Clin. Chim. Acta, v.369, n.1, p.1-16, 2006.

FRIED, S.K.; GREENBERG, A.S. Lipocalin 2: a "sexy" adipokine that regulates $17 \beta$-estradiol and obesity. Endocrinology, v.153, n.4, p.1582-1584, 2012.

FUJIKAWA, T.; BERGLUND, E.D.; PATEL, V.R.; RAMADORI, G.; VIANNA, C.R.; VONG, L.; THOREL, F.; CHERA, S.; HERRERA, P.L.; LOWELL, B.B.; ELMQUIST, J.K.; BALDI, P.; COPPARI, R. Leptin engages a hypothalamic neurocircuitry to permit survival in the absence of insulin. Cell Metab., v.18, n.3, p.431-444, 2013.
GALIC, S.; OAKHILL, J.S.; STEINBERG, G.R. Adipose tissue as an endocrine organ. Mol. Cell. Endocrinol., v.316, n.2, p.129-139, 2010.

GAVI, S.; STUART, L.M.; KELLY, P.; MELENDEZ, M.M.; MYNARCIK, D.C.; GELATO, M.C.; MCNURLAN, M.A. Retinol-binding protein 4 is associated with insulin resistance and body fat distribution in nonobese subjects without type 2 diabetes. J. Clin. Endocrinol. Metab., v.92, n.5, p.1886-1890, 2007.

GOLDFINE, A.B.; FONSECA, V.; JABLONSKI, K.A.; PYLE, L.; STATEN, M.A.; SHOELSON, S.E. The effects of salsalate on glycemic control in patients with type 2 diabetes: a randomized trial. Ann. Intern. Med., v.152, n.6, p.346-357, 2010.

GONG, N.; ZHANG, H.B.; FANG, F.D.; CHANG, Y.S. Adenovirus construction of expression and it's function of connective tissue growth factor. Zhongguo Yi Xue Ke Xue Yuan Xue Bao, v.33, n.6, p.649-653, 2011.

GOYAL, R.K.; LIN, Y.; SCHULTZ, K.R.; FERRELL, R.E.; KIM, Y.; FAIRFULL, L.; LIVOTE, E.; YANIK, G.; ATLAS, M. Tumor necrosis factor-alpha gene polymorphisms are associated with severity of acute graft-versushost disease following matched unrelated donor bone marrow transplantation in children: a pediatric blood and marrow transplant consortium study. Biol. Blood Marrow Transplant., v.16, n.7, p.927-936, 2010.

GRAY, S.L.; VIDAL-PUIG, A.J. Adipose tissue expandability in the maintenance of metabolic homeostasis. Nutr. Rev., v.65, n.6, p.S7-S12, 2007.

HAJRI, T.; TAO, H.; WATTACHERIL, J.; MARKS-SHULMAN, P.; ABUMRAD, N.N. Regulation of adiponectin production by insulin: interactions with tumor necrosis factor- $\alpha$ and interleukin-6. Am. J. Physiol. Endocrinol. Metab., v.300, n.2, p.E350-E360, 2011.

HAYDEN, M.S.; GHOSH, S. Signaling to NF-kappaB. Genes Dev., v.18, n.18, p.2195-2224, 2004.

HEILBRONN, L.K.; ROOD, J.; JANDEROVA, L.; ALBU, J.B.; KELLEY, D.E.; RAVUSSIN, E.; SMITH, S.R. Relationship between serum resistin concentrations and insulin resistance in nonobese, obese, and obese diabetic subjects. J. Clin. Endocrinol. Metab., v.89, n.4, p.1844-1848, 2004. 
HERMSDORFF, H.H.; ZULET, M.A.; PUCHAU, B.; MARTÍNEZ, J.A. Central adiposity rather than total adiposity measurements are specifically involved in the inflammatory status from healthy young adults. Inflammation, v.34, n.3, p.161-170, 2011.

HOTAMISLIGIL, G.S.; ERBAY, E. Nutrient sensing and inflammation in metabolic diseases. Nat. Rev. Immunol., v.8, n.12, p.923-934, 2008.

HU, Z.; DENG, H.; QU, H. Plasma SFRP5 levels are decreased in chinese subjects with obesity and type 2 diabetes and negatively correlated with parameters of insulin resistance. Diabetes Res. Clin. Pract., v.99, n.3, p.391-395, 2013.

IACOBELLIS, G.; LEONETTI, F. Epicardial adipose tissue and insulin resistance in obese subjects. J. Clin. Endocrinol. Metab., v.90, n.11, p.6300-6302, 2005.

JI, Z.Z.; DAI, Z.; XU, Y.C. A new tumor necrosis factor (TNF)- $\alpha$ regulator, lipopolysaccharides-induced TNF- $\alpha$ factor, is associated with obesity and insulin resistance. Chin. Med. J. (Engl.), v.124, n.2, p.177-182, 2011.

JUNQUEIRA, A.S.; ROMÊO FILHO, L.J.; JUNQUEIRA, C.E.L. Evaluation of the degree of vascular inflammation in patients with metabolic syndrome. Arq. Bras. Cardiol., v.93, n.4, p.360-366, p.353-359, 2009.

KADOWAKI, T.; YAMAUCHI, T.; KUBOTA, N. The physiological and pathophysiological role of adiponectin and adiponectin receptors in the peripheral tissues and CNS. FEBS Lett., v.582, n.1, p.74-80, 2008.

KAHN, B.B.; MINOKOSHI, Y. Leptin, GABA, and glucose control. Cell Metab., v.18, n.3, p.304-306, 2013.

KAMATA, M.; TADA, Y.; TATSUTA, A.; KAWASHIMA, T.; SHIBATA, S.; MITSUI, H.; ASANO, Y.; SUGAYA, M.; KADONO, T.; KANDA, N.; WATANABE, S.; SATO, $\mathrm{S}$. Serum lipocalin-2 levels are increased in patients with psoriasis. Clin. Exp. Dermatol., v.37, n.3, p.296-299, 2012.

KASER, S.; KASER, A.; SANDHOFER, A.; EBENBICHLER, C.F.; TILG, H.; PATSCH, J.R. Resistin messenger-RNA expression is increased by proinflammatory cytokines in vitro. Biochem. Biophys. Res. Commun., v.309, n.2, p.286290, 2003.
KAWANAMI, D.; MAEMURA, K.; TAKEDA, N.; HARADA, T.; NOJIRI, T.; IMAI, Y.; MANABE, I.; UTSUNOMIYA, K.; NAGAI, R. Direct reciprocal effects of resistin and adiponectin on vascular endothelial cells: a new insight into adipocytokine-endothelial cell interactions. Biochem. Biophys. Res. Commun., v.314, n.2, p.415-419, 2004.

KIGUCHI, N.; MAEDA, T.; KOBAYASHI, Y.; FUKAZAWA, Y.; KISHIOKA, S. Leptin enhances CC-chemokine ligand expression in cultured murine macrophage. Biochem. Biophys. Res. Commun., v.384, n.3, p.311-315, 2009.

KLÖTING, N.; GRAHAM, T.E.; BERNDT, J.; KRALISCH, S.; KOVACS, P.; WASON, C.J.; FASSHAUER, M.; SCHÖN, M.R.; STUMVOLL, M.; BLÜHER, M.; KAHN, B.B. Serum retinol-binding protein is more highly expressed in visceral than in subcutaneous adipose tissue and is a marker of intra-abdominal fat mass. Cell. Metab., v.6, n.1, p.79-87, 2007.

KOZA, R.A.; NIKONOVA, L.; HOGAN, J.; RIM, J.S.; MENDOZA, T.; FAULK, C.; SKAF, J.; KOZAK, L.P. Changes in gene expression foreshadow diet-induced obesity in genetically identical mice. Plos Genet., v.2, n.5, p.e81, 2006.

KRENTZ, A.J.; VON MÜHLEN, D.; BARRETT-CONNOR, E. Adipocytokines, sex hormones, and cardiovascular risk factors in postmenopausal women: factor analysis of the Rancho Bernardo study. Horm. Metab. Res., v.41, n.10, p.773-777, 2009.

KÖNNER, A.C.; BRÜNING, J.C. Toll-like receptors: linking inflammation to metabolism. Trends. Endocrinol. Metab., v.22, n.1, p.16-23, 2011

LANDSKRONER-EIGER, S.; QIAN, B.; MUISE, E.S.; NAWROCKI, A.R.; BERGER, J.P.; FINE, E.J.; KOBA, W.; DENG, Y.; POLLARD, J.W.; SCHERER, P.E. Proangiogenic contribution of adiponectin toward mammary tumor growth in vivo. Clin. Cancer Res., v.15, n.10, p.3265-3276, 2009.

LAW, I.K.; XU, A.; LAM, K.S.; BERGER, T.; MAK, T.W.; VANHOUTTE, P.M.; LIU, J.T.; SWEENEY, G.; ZHOU, M.; YANG, B.; WANG, Y. Lipocalin-2 deficiency attenuates insulin resistance associated with aging and obesity. Diabetes, v.59, n.4, p.872-882, 2010. 
LEE, D.C.; LEE, J.W.; IM, J.A. Association of serum retinol binding protein 4 and insulin resistance in apparently healthy adolescents. Metabolism, v.56, n.3, p.327-331, 2007.

LEE, J.H.; CHAN, J.L.; YIANNAKOURIS, N. ; KONTOGIANNI, M.; ESTRADA, E.; SEIP, R.; ORLOVA. C.; MANTZOROS, C.S. Circulating resistin levels are not associated with obesity or insulin resistance in humans and are not regulated by fasting or leptin administration: cross-sectional and interventional studies in normal, insulinresistant, and diabetic subjects. J. Clin. Endocrinol. Metab., v.88, n.10, p.4848-4856, 2003.

LEHRKE, M.; REILLY, M.P.; MILLINGTON, S.C.; IQBAL, N.; RADER, D.J.; LAZAR, M.A. An inflammatory cascade leading to hyperresistinemia in humans. Plos Med., v.1, n.2, p.e45, 2004.

LI, Q.; VERMA, I.M. NF-kappaB regulation in the immune system. Nat. Rev. Immunol., v.2, n.10, p.725-734, 2002.

LIN, H.; LI, Z. Adiponectin self-regulates its expression and multimerization in adipose tissue: an autocrine/paracrine mechanism? Med. Hypotheses, v.78, n.1, p.75-78, 2012.

LIU, M.; LIU, F. Transcriptional and post-translational regulation of adiponectin. Biochem. J., v.425, n.1, p.41-52, 2010 .

LV, C.; JIANG, Y.; WANG, H.; CHEN, B. SFRP5 expression and secretion in adipocyte are upregulated during the differentiation and are negatively correlated with insulin resistance. Cell. Biol. Int., v.36, n.9, p.851-855, 2012.

MCGOWN, C.; BIRERDINC, A.; YOUNOSSI, Z.M. Adipose tissue as an endocrine organ. Clin. Liver Dis. v.1, n.18, p.41-58, 2014.

MRACEK, T.; GAO, D.; TZANAVARI, T.; BAO, Y.; XIAO, X.; STOCKER, C.; TRAYHURN, P.; BING, C. Downregulation of zinc-\{alpha\}2-glycoprotein in adipose tissue and liver of obese ob/ob mice and by tumour necrosis factor-alpha in adipocytes. J. Endocrinol., v.204, n.2, p.165-172, 2010.

MYERS, M.G.; HEYMSFIELD, S.B.; HAFT, C.; KAHN, B.B.; LAUGHLIN, M.; LEIBEL, R.L.; TSCHÖP, M.H.; YANOVSKI, J.A. Challenges and opportunities of defining clinical leptin resistance. Cell. Metab., v.15, n.2, p.150-156, 2012.
MYERS, M.G.; LEIBEL, R.L.; SEELEY, R.J.; SCHWARTZ, M.W. Obesity and leptin resistance: distinguishing cause from effect. Trends Endocrinol. Metab., v.21, n.11, p.643$651,2010$.

MYERS, M.G.; MÜNZBERG, H.; LEINNINGER, G.M.; LESHAN, R.L. The geometry of leptin action in the brain: more complicated than a simple ARC. Cell. Metab., v.9, n.2, p.117-123, 2009.

NAKAMURA, Y.; SEKIKAWA, A.; KADOWAKI, T.; KADOTA, A.; KADOWAKI, S.; MAEGAWA, H.; KITA, Y.; EVANS, R.W.; EDMUNDOWICZ, D.; CURB, J.D.; UESHIMA, H. Visceral and subcutaneous adiposity and adiponectin in middle-aged Japanese men: the Era Jump study. Obesity, v.17, n.6, p.1269-1273, 2009.

NISHIDA, M.; MORIYAMA, T.; ISHII, K.; TAKASHIMA, S.; YOSHIZAKI, K.; SUGITA, Y.; YAMAUCHI-TAKIHARA, K. Effects of IL-6, adiponectin, CRP and metabolic syndrome on subclinical atherosclerosis. Clin. Chim. Acta, v.384, n.1-2, p.99-104, 2007.

OHASHI, K.; PARKER, J.L.; OUCHI, N.; HIGUCHI, A.; VITA, J.A.; GOKCE, N.; PEDERSEN, A.A.; KALTHOFF, C.; TULLIN, S.; SAMS, A.; SUMMER, R.; WALSH K. Adiponectin promotes macrophage polarization toward an anti-inflammatory phenotype. J. Biol. Chem., v.285, n.9, p.6153-6160, 2010.

OH, D.Y.; OLEFSKY, J.M. Medicine: fans the flames in obesity. Science, v.329, n.5990, p.397-398, 2010.

OUCHI, N.; HIGUCHI, A.; OHASHI, K.; OSHIMA, Y.; GOKCE, N.; SHIBATA, R.; AKASAKI, Y.; SHIMONO, A.; WALSH, K. SFRP5 is an anti-inflammatory adipokine that modulates metabolic dysfunction in obesity. Science, v.329, n.5990, p.454-457, 2010.

OUCHI, I.N.; KIHARA, S.; FUNAHASHI, T.; MATSUZAWA, Y.; WALSH, K. Obesity, adiponectin and vascular inflammatory disease. Curr. Opin. Lipidol., v.14, n.6, p.561$566,2003$.

OUCHI, N.; PARKER, J.L.; LUGUS, J.J.; WALSH, K. Adipokines in inflammation and metabolic disease. Nat. Rev. Immunol., v.11, n.2, p.85-97, 2011. 
OZCAN, L.; ERGIN, A.S.; LU, A.; CHUNG, J.; SARKAR, S.; NIE, D.; MYERS JR., M.G.; OZCAN, U. Endoplasmic reticulum stress plays a central role in development of leptin resistance. Cell. Metab., v.9, n.1, p.35-51, 2009.

PATEL, S.D.; RAJALA, M.W.; ROSSETTI, L.; SCHERER, P.E.; SHAPIRO, L. Disulfide-dependent multimeric assembly of resistin family hormones. Science, v.304, n.5674, p.1154-1158, 2004.

POPEIJUS, H.E.; SARIS, W.H.; MENSINK, R.P. Role of stearoyl-CoA desaturases in obesity and the metabolic syndrome. Int. J. Obes., v.32, n.7, p.1076-1082, 2008.

PUGLISI, M.J.; FERNANDEZ, M.L. Modulation of C-reactive protein, tumor necrosis factor-alpha, and adiponectin by diet, exercise, and weight loss. J. Nutr., v.138, n.12, p.22932296, 2008.

QATANANI, M.; SZWERGOLD, N.R.; GREAVES, D.R.; AHIMA, R.S.; LAZAR, M.A. Macrophage-derived human resistin exacerbates adipose tissue inflammation and insulin resistance in mice. J. Clin. Invest., v.119, n.3, p.531-539, 2009.

QI, Y.; NIE, Z.; LEE, Y.S.; SINGHAL, N.S.; SCHERER, P.E.; LAZAR, M.A.; AHIMA, R.S. Loss of resistin improves glucose homeostasis in leptin deficiency. Diabetes, v.55, n.11, p.3083-3090, 2006.

RAJALA, M.W.; QI, Y.; PATEL, H.R.; TAKAHASHI, N.; BANERJEE, R.; PAJVANI, U.B.; SINHA, M.K.; GINGERICH, R.L.; SCHERER, P.E.; AHIMA, R.S. Regulation of resistin expression and circulating levels in obesity, diabetes, and fasting. Diabetes, v.53, n.7, p.1671$1679,2004$.

RATTNER, A.H.J.; SMALLWOOD, P.M.; GILBERT, D.J.; COPELAND, N.G.; JENKINSNA, N.J. A family of secreted proteins containshomology to the cysteine-rich ligand-binding domain of frizzled receptors. Proc. Natl. Acad.Sci., v.94, n.7, p.2859-2863, 1997.

REXRODE, K.M.; PRADHAN, A.; MANSON, J.E.; BURING, J.E.; RIDKER, P.M. Relationship of total and abdominal adiposity with CRP and IL-6 in women. Ann. Epidemiol., v.13, n.10, p.674-682, 2003.
REYNA, S.M.; GHOSH, S.; TANTIWONG, P.; MEKA, C.S.; EAGAN, P.; JENKINSON, C.P.; CERSOSIMO, E.; DEFRONZO, R.A.; COLETTA, D.K.; SRIWIJITKAMOL, A.; MUSI, N. Elevated toll-like receptor 4 expression and signaling in muscle from insulin-resistant subjects. Diabetes, v.57, n.10, p.2595-2602, 2008.

ROLLI, V.; RADOSAVLJEVIC, M.; ASTIER, V.; MACQUIN, C.; CASTAN-LAURELL, I.; VISENTIN, V.; GUIGNÉ, C.; CARPÉNÉ, C.; VALET, P.; GILFILLAN, S.; BAHRAM, $\mathrm{S}$. Lipolysis is altered in MHC class I zinc-alpha(2)glycoprotein deficient mice. FEBS Lett., v.581, n.3, p.394400, 2007.

ROSE, D.P.; KOMNINOU, D.; STEPHENSON, G.D. Obesity, adipocytokines, and insulin resistance in breast cancer. Obes. Rev., v.5, n.3, p.153-165, 2004.

SADAGURSKI, M.; LESHAN, R.L.; PATTERSON, C.; ROZZO, A.; KUZNETSOVA, A.; SKORUPSKI, J.; JONES, J.C.; DEPINHO, R.A.; MYERS JR, M.G.; WHITE, M.F. IRS2 signaling in LepR-b neurons suppresses FoxO1 to control energy balance independently of leptin action. Cell. Metab., v.15, n.5, p.703-712, 2012.

SANTOS-ALVAREZ, J.; GOBERNA, R.; SÁNCHEZMARGALET, V. Human leptin stimulates proliferation and activation of human circulating monocytes. Cell. Immunol., v.194, n.1, p.6-11, 1999.

SAVAGE, D.B.; SEWTER, C.P.; KLENK, E.S.; SEGAL, D.G.; VIDAL-PUIG, A.; CONSIDINE, R.V.; O'RAHILLY, S. Resistin / Fizz3 expression in relation to obesity and peroxisome proliferator-activated receptor-gamma action in humans. Diabetes, v.50, n.10, p.2199-2202, 2001.

SCHULTE, D.M.; MULLER, N.; NEUMANN, K.; OBERHAUSER, F.; FAUST, M.; GUDELHOFER, H.; BRANDT, B.; KRONE,W.; LAUDES, M. Pro-inflammatory 5a and anti-inflammatory SFRP5 are differentially regulated by nutritional factors in obese human subjects. Plos One, v.7, n.2, p.e32437, 2012.

SERRANO-MARCO, L.; CHACÓN, M.R.; MAYMÓMASIP, E.; BARROSO, E.; SALVADÓ L.; WABITSCH, M.; GARRIDO-SÁNCHEZ, L.; TINAHONES, F.J.; PALOMER, X.; VENDRELL, J.; VÁZQUEZ-CARRERA, M. TNF- $\alpha$ inhibits PPAR $\beta / \delta$ activity and SIRT1 expression through NF- $\kappa \mathrm{B}$ in human adipocytes. Biochim. Biophys. Acta, v.1821, n.9, p.1177-1185, 2012. 
SINGH, P.; PETERSON, T.E.; SERT-KUNIYOSHI, F.H.; GLENN, J.A.; DAVISON, D.E.; ROMERO-CORRAL, A.; PUSALAVIDYASAGAR, S.; JENSEN, M.D.; SOMERS, V. Leptin signaling in adipose tissue: role in lipid accumulation and weight gain. Circ. Res., v.111, n.5, p.599-603, 2012.

SMITH, C.M.M.A., LIEBERMAN, M.A.; MARKS, D.B. Synthesis of fatty acids, triacylglycerols, and the major membrane lipids. Philadelphia: Marks' basic medical biochemistry: a clinical approach, 2005. p.594-618.

SPALDING, K.L.; ARNER, E.; WESTERMARK, P.O.; WESTERMARK, P.O.; BERNARD, S.; BUCHHOLZ, B.A.; BERGMANN, O.; BLOMQVIST, L.; HOFFSTEDT, J.; NÄSLUND, E.; BRITTON, T.; CONCHA, H.; HASSAN, M.; RYDÉN, M.; FRISÉN, J.; ARNER, P. Dynamics of fat cell turnover in humans. Nature, v.453, n.7196, p.783-787, 2008.

SRINIVASAN, S.; LEEMAN, S.E.; AMAR, S. Beneficial dysregulation of the time course of inflammatory mediators in lipopolysaccharide-induced tumor necrosis factor alpha factor-deficient mice. Clin. Vaccine Immunol., v.17, n.5, p.699-704, 2010.

ST-PIERRE, J.; TREMBLAY, M.L. Modulation of leptin resistance by protein tyrosine phosphatases. Cell. Metab., v.15, n.3, p.292-297, 2012.

STEPPAN, C.M.; BAILEY, S.T.; BHAT, S.; BROWN, E.J.; BANERJEE, R.R.; WRIGHT, C.M.; PATEL, H.R.; AHIMA, R.S.; LAZAR, M.A. The hormone resistin links obesity to diabetes. Nature, v.409, n.6818, p.307-312, 2001.

STEPPAN, C.M.; WANG, J.; WHITEMAN, E.L.; BIRNBAUM, M.J.; LAZAR, M.A. Activation of SOCS-3 by resistin. Mol. Cell. Biol., v.25, n.4, p.1569-1575, 2005.

TANABE, K.; MATSUSHIMA - NIS HIWAKI, R.; YAMAGUCHI, S.; IIDA, H.; DOHI, S.; KOZAW, A.O. Mechanisms of tumor necrosis factor-alpha-induced interleukin-6 synthesis in glioma cells. J. Neuroinflamm., v.7, n.16, p.1-8, 2010.

TANG, X.; FENTON, M.J.; AMAR, S. Identification and functional characterization of a novel binding site on TNFalpha promoter. Proc. Natl. Acad. Sci. U. S. A., v.100, n.7, p.4096-4101, 2003.
TANG, X.; MARCIANO, D.L.; LEEMAN, S.E.; AMAR, S. LPS induces the interaction of a transcription factor, LPSinduced TNF-alpha factor, and STAT6(B) with effects on multiple cytokines. Proc. Natl. Acad. Sci. U. S. A., v.102, n.14, p.5132-5137, 2005.

TANG, X.; METZGER, D.; LEEMAN, S.; AMAR, S. LPSinduced TNF-alpha factor (LITAF)-deficient mice express reduced LPS-induced cytokine: Evidence for LITAFdependent LPS signaling pathways. Proc. Natl. Acad. Sci. U. S. A., v.103, n.37, p.13777-13782, 2006.

TORRES-LEAL, F.L.; FONSECA-ALANIZ, M.H.; ROGERO, M.M.; TIRAPEGUI, J. The role of inflamed adipose tissue in the insulin resistance. Cell. Biochem. Funct., v.28, n.8, p.623-631, 2010.

TORRES-LEAL, F.L.; FONSECA-ALANIZ, M.H.; TEODORO, G.F.; CAPITANI, M.D.; VIANNA, D.; PANTALEÃO, L.C.; MATOS-NETO, E.M.; ROGERO, M.M.; DONATO, J.; TIRAPEGUI, J. Leucine supplementation improves adiponectin and total cholesterol concentrations despite the lack of changes in adiposity or glucose homeostasis in rats previously exposed to a high-fat diet. Nutr. Metab., v.8, n.1, p.62, 2011.

VERMA, S.; LI, S.H.; WANG, C.H.; FEDAK, P.W.; LI, R.K.; WEISEL, R.D.; MICKLE, D.A. Resistin promotes endothelial cell activation: further evidence of adipokineendothelial interaction. Circulation, v.108, n.6, p.736-740, 2003.

VIOLLET, B.; FORETZ, M.; GUIGAS, B.; HORMAN, S.; DENTIN, R.; BERTRAND, L.; HUE, L.; ANDREELLI, F. Activation of AMP-activated protein kinase in the liver: a new strategy for the management of metabolic hepatic disorders. J. Physiol., v.574, n.1, p.41-53, 2006.

VIRTUE, S.; VIDAL-PUIG, A. Adipose tissue expandability, lipotoxicity and the Metabolic Syndrome--an allostatic perspective. Biochim. Biophys. Acta., v.1801, n.3, p.338349, 2010.

VOLP, A.C.; ALFENAS, R.C.; COSTA, N.M.; MINIM, V.P.; STRINGUETA, P.C.; BRESSAN, J. Inflammation biomarkers capacity in predicting the metabolic syndrome. Arq. Bras. Endocrinol. Metabol., v.52, n.3, p.537-549, 2008. 
VU, V.; RIDDELL, M.C.; SWEENEY, G. Circulating adiponectin and adiponectin receptor expression in skeletal muscle: effects of exercise. Diabetes Metab. Res. Rev., v.23, n.8, p.600-611, 2007.

WANG, J.; YU, L.; SCHMIDT, R.E.; SU, C.; HUANG, X.; GOULD, K.; CAO, G. Characterization of HSCD5, a novel human stearoyl-CoA desaturase unique to primates. Biochem. Biophys. Res. Commun., v.332, n.3, p.735-742, 2005.

WANG, Y.; LAM, K.S.; KRAEGEN, E.W.; SWEENEY, G.; ZHANG, J.; TSO, A.W.; CHOW, W.S.; WAT, N.M.; XU, J.Y.; HOO, R.L.; XU, A. Lipocalin-2 is an inflammatory marker closely associated with obesity, insulin resistance, and hyperglycemia in humans. Clin. Chem., v.53, n.1, p.34-41, 2007.

WANG, Z.V.; SCHERER, P.E. DsbA-L is a versatile player in adiponectin secretion. Proc. Natl. Acad. Sci. U. S. A., v.105, n. 47, p.18077-18078, 2008.

WAY, J.M.; GÖRGÜN, C.Z.; TONG, Q.; UYSAL, K.T.; BROWN, K.K.; HARRINGTON, W.W.; OLIVER JR, W.R.; WILLSON, T.M.; KLIEWER, S.A.; HOTAMISLIGIL, G.S. Adipose tissue resistin expression is severely suppressed in obesity and stimulated by peroxisome proliferator-activated receptor gamma agonists. J. Biol. Chem., v.276, n.28, p.25651-25653, 2001.

WELLEN, K.E.; HOTAMISLIGIL, G.S. Inflammation, stress, and diabetes. J. Clin. Invest., v.115, n.5, p.1111-1119, 2005.

WHITE, P.B.; TRUE, E.M.; ZIEGLER, K.M.; WANG, S.S.; SWARTZ-BASILE, D.A.; PITT, H.A.; ZYROMSKI, N.J. Insulin, leptin, and tumoral adipocytes promote murine pancreatic cancer growth. J. Gastrointest. Surg., v.14, n.12, p.1888-1894, 2010.

YAMAUCHI, T.; KAMON, J.; MINOKOSHI, Y.; ITO, Y.; WAKI, H.; UCHIDA, S.; YAMASHITA, S.; NODA, M.; KITA, S.; UEKI, K.; ETO, K.; AKANUMA, Y.; FROGUEL, P.; FOUFELLE, F.; FERRE, P.; CARLING, D.; KIMURA, S.; NAGAI, R.; KAHN, B.B.; KADOWAKI, T. Adiponectin stimulates glucose utilization and fatty-acid oxidation by activating AMP-activated protein kinase. Nat. Med., v.8, n.11, p.1288-1295, 2002.
YAN, Q.W.; YANG, Q.; MODY, N.; GRAHAM, T.E.; HSU, C.H.; XU, Z.; HOUSTIS, N.E.; KAHN, B.B.; ROSEN, E.D. The adipokine lipocalin 2 is regulated by obesity and promotes insulin resistance. Diabetes, v.56, n.10, p.25332540, 2007.

YANG, Q.; GRAHAM, T.E.; MODY, N.; PREITNER, F.; PERONI, O.D.; ZABOLOTNY, J.M.; KOTANI, K.; QUADRO, L.; KAHN, B.B. Serum retinol binding protein 4 contributes to insulin resistance in obesity and type 2 diabetes. Nature, v.436, n.7049, p.356-362, 2005.

ZHANG, J.; SCARPACE, P.J. The soluble leptin receptor neutralizes leptin-mediated STAT3 signalling and anorexic responses in vivo. Br. J. Pharmacol., v.158, n.2, p.475-482, 2009.

ZHANG, J.; WU, Y.; ZHANG, Y.; LEROITH, D.; BERNLOHR, D.A.; CHEN, X. The role of lipocalin 2 in the regulation of inflammation in adipocytes and macrophages. Mol. Endocrinol., v.22, n.6, p.1416-1426, 2008.

ZHANG, L.; GE, L.; PARIMOO, S.; STENN, K.; PROUTY, S.M. Human stearoyl-CoA desaturase: alternative transcripts generated from a single gene by usage of tandem polyadenylation sites. Biochem. J., v.340, Pt.1, p.255-264, 1999.

ZHANG, S.; YANG, Y.; SHI, Y. Characterization of human $\mathrm{SCD} 2$, an oligomeric desaturase with improved stability and enzyme activity by cross-linking in intact cells. Biochem. $J .$, v.388, Pt.1, p.135-142, 2005.

ZICCARDI, P.; NAPPO, F.; GIUGLIANO, G.; ESPOSITO, K.; MARFELLA, R.; CIOFFI, M.; D'ANDREA, F.; MOLINARI, A.M.; GIUGLIANO, D. Reduction of inflammatory cytokine concentrations and improvement of endothelial functions in obese women after weight loss over one year. Circulation, v.105, n.7, p.804-809, 2002.

Received for publication on $31^{\text {st }}$ July 2013 Accepted for publication on $09^{\text {th }}$ Mach 2014 